Pamiętnik Literacki 2020, 4, s. 31-43

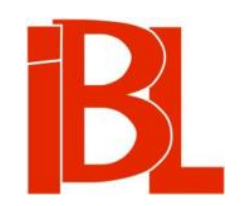

\title{
Zmierzch edycji krytycznych?
}

\author{
Maria Prussak
}


Pamiętnik Literacki CXI, 2020, z. 4, PL ISSN 0031-0514

DOI: $10.18318 / \mathrm{pl} .2020 .4 .3$

MARIA PRUSSAK Instytut Badań Literackich PAN, Warszawa

\title{
ZMIERZCH EDYCJI KRYTYCZNYCH?
}

\author{
Dumny $z$ władzy nad ludźmi dawno minionymi \\ Zmieniaj przeszłość na własne, lepsze podobieństwo.
}

Cz. Miłosz, Dziecię Europy

Edytorzy tradycjonaliści z niezmąconą wiernością realizują założenia wypracowane w szkole Konrada Górskiego. Przekonani o tym, że tworzą twardą, obiektywną wiedzę, posługują się kategoriami ze świata naukowej utopii, w którym przeciwieństwa przestają być opozycjami, a arbitralne decyzje mają moc ostatecznego rozstrzygania wątpliwości. Podstawę tego utopijnego świata stanowi przekonanie, iż edytorstwo jest dziedzina służebną, praca laboratoryjną i ma przygotować dla uczonych prowadzących badania właściwe, tzn. zajmujących sie procesem historycznoliterackim i interpretowaniem dzieł, tekst, który jest najwierniejszym wyrazem woli autora. Aby laboratorium funkcjonowało bez zakłócen, powinno się kierować jednolitymi, weryfikowalnymi, w miarę możliwości uniwersalnymi zasadami ${ }^{1}$. Kryteria weryfikacji są definiowane dość ogólnie jako sprawdzone „procedury filologiczne"2. W szkole tej dominuje przeświadczenie o istnieniu właściwego tekstu, nietożsamego $z$ jego materialnymi przekazami. Trudno o odpowiedź na pytanie gdzie się ten tekst znajduje i z jakich źródeł pochodzi wiedza o nim, często $z$ intuicji wspieranej odwołaniami do hermeneutyki. Do zadań edytora należy uzyskanie „właściwego, to jest poprawnego, zgodnego z intencją autorską, najlepszego kształtu dzieła” ${ }^{3}$. Uzyskanie droga dedukcji i rekonstrukcji. W wielu przekazach trzeba więc wytropić ślady jednej niezmiennej intencji, co, jak łatwo zauważyć, daje edytorowi nieograniczoną możliwość kompilacji źródeł, poprawiania miejsc uznanych za zniekształcone i interpretacyjnej dowolności. Dużo w tak konstruowanej definicji terminów wartościujących, brakuje tekstologicznych konkretów ${ }^{4}$. W świecie utopii konkrety zwykle zamazują optymistyczną wyrazistość obrazu. W praktycznym działaniu to konkrety stawiaja pytania rozsadzające przyjęte z góry zasady postępowania.

1 Zob. np. Od redakcji. W zb.: Jak wydawać teksty dawne. Red. K. Borowiec, D. Masłej, T. Mika, D. Rojszczak-Robińska. Poznań 2017, s. 8.

2 R. Grześk kow i a k, Stary druk jako podstawa edycji krytycznej. Preliminaria. W zb.: jw., s. 32.

3 T. Ch a chuls ki, Edytorstwo naukowe jako historia literatury $i$ inne studia o poezji XVIII wieku. Warszawa 2019, s. 11.

4 Współczesny chaos w terminologii i praktyce edytorskiej brawurowo omówił P. B e m (Dlaczego polskie edytorstwo naukowe nie istnieje. „Teksty Drugie” 2016, nr 1) w artykule, który wywołał wzburzenie w środowisku edytorów. 
Od kiedy w polskim literaturoznawstwie zaczęto opracowywać teoretyczne podstawy naukowych wydań tekstów nowożytnych, edytorzy zastanawiali się nad sposobami rozwiązywania problemów, z którymi musieli się mierzyć, śledzili i komentowali ustalenia badaczy z innych krajów. Bardzo pod tym względem pouczający jest artykuł Anny Chorowiczowej Wydanie tekstów najnowszych $w$ świetle niektórych publikacyj doby ostatniej ${ }^{5}$, który ukazał się na początku lat dwudziestych minionego wieku. Autorka przedstawiła w nim różnorodność stanowisk w najnowszych wówczas francuskich i niemieckich pracach dotyczących teoretycznych zasad edytorstwa. Do przywołanych przez nią tytułów nawiązywali następnie badacze kolejnych generacji, znalazły się np. w bibliografii podręcznika Romana Lotha ${ }^{6}$. Co ciekawe, Chorowiczowa zwróciła uwagę na znaczenie edycji symultanicznych, wydobywając z zapomnienia zlekceważoną przez współczesnych i późniejszych literaturoznawców publikację Ifigenii w Taurydzie Johanna Wolfganga Goethego. Szwajcarski filolog, Jakob Baechtold, szczegółowo omówił cztery istniejące przekazy dramatu Goethego (dwa prozatorskie i dwa wierszowane) i postanowił wydrukować je w jednym tomie obok siebie, w czterech równoległych szpaltach rozmieszczonych na dwu stronicach, tworząc zaczątek współczesnej krytyki genetycznej ${ }^{7}$. Książka ukazała się w 1883 roku. W dziełach Goethego publikuje się jedyną ogłoszona za życia, ostatnią wersję napisana 5-stopowym jambem ${ }^{8}$, Baechtold udostępnił badaczom kolejne etapy ewolucji dramatu $-\mathrm{z}$ roku: $1779,1780,1781$, wreszcie $\mathrm{z}$ lat 1786-1787. Proces twórczy był, jak można sądzić $z$ nielicznych wydrukowanych pism, głównym tematem zainteresowań Chorowiczowej. Wiele miejsca poświęciła mu w rozprawie o Konfederatach barskich Adama Mickiewicza, różne rękopiśmienne wersje wierszy Adama Asnyka zestawiła w oddzielnym artykule poświęconym możliwościom rekonstrukcji pracy poety nad tekstem ${ }^{9}$.

Kiedy dwa lata wcześniej Wilhelm Bruchnalski przedstawiał kanon wydawniczy dzieł Mickiewicza, podkreślał, że brakuje w Polsce solidnej „teorii sztuki wydawniczej” ${ }^{10}$. Zaczynał więc od pokazania złożonej sytuacji tekstologicznej i niejednoznaczności decyzji, które staną przed edytorami. Próbował zarysować nieprzekraczalne ramy nieuniknionej arbitralności. Zaproponował formułe, która zyskuje popularność w najnowszej tekstologii. Obserwując to samo zjawisko, wyciagnął jednak wnioski inne niż dzisiejsi badacze:

Książka, która przedstawia ustaleni e płynnego stanu twórczości literackiej, przejawiającego się w mniejszej lub większej ilości redakcyj rękopiśmiennych tego samego dzieła, czy mniejszej lub większej ilości jego mniej lub bardziej zmienionych wydań drukowanych, musi być wynikiem ustalenia,

5 A. Ch or ow i c zow a, Wydanie tekstów najnowszych $w$ świetle niektórych publikacyj doby ostatniej. „Pamiętnik Literacki” t. 21 (1924/25), z. 1/4.

6 R. L o th, Podstawowe pojęcia i problemy tekstologii i edytorstwa naukowego. Warszawa 2006.

7 Goethes „Iphigenie auf Tauris” in vierfacher Gestalt. Herausg. J. B a e c h t old. Freiburg im Breisgau - Tübingen 1883. Korzystam ze współczesnego reprintu sporządzonego przez wydawnictwo „BiblioLife” (Charleston [2020]).

8 J. W. G o e th e, Iphigenie auf Tauris. Ein Schauspiel. W: Schriften. T. 3. Leipzig 1787.

9 A. Ch or ow i c z ow a: O „Konfederatach barskich” Adama Mickiewicza. Warszawa 1922; Na marginesie nieznanych utworów Adama Asnyka. „Pamiętnik Literacki” t. 22/23 (1925/26), z. 1/4.

10 W. Bruchnalski, Próba kanonu wydawniczego $w$ zastosowaniu do zbiorowej edycji „Dzieł wszystkich” Mickiewicza. „Pamiętnik Literacki” t. 20 (1923), z. 1/4, s. 128. 
dokonanego na podstawie pewnych zasad, które, jeżeli będą zgodne z zasadami nauki, sprawią, że książka otrzyma epitet: wyda nej naukowo, w razie przeciwnym będzie wydawnictwem nienaukowy ${ }^{11}$.

W roku 1922 zadaniem edytora było stabilizowanie tekstu, dziś tekstologię bardziej interesuje jego dynamika, płynność przejawiająca się w wielowariantowości.

Warto jeszcze przypomnieć uwagi Bruchnalskiego na temat dopuszczalnych korekt wprowadzanych do tekstu autorskiego:

Korektura jednak może być stosowana bez zastrzeżeń jakichkolwiek tylko wtedy, kiedy to, co wymaga poprawienia, należy niewątpliwie albo do „błędów pióra” Poety albo do zniekształc e ń, wynikłych $z$ błędów drukarza lub przepisywacza.

Błędów Poety w budowie wi er sza, np. skutkiem braku jednej lub więcej zgłosek albo skutkiem pomylonej rytmiczności (przestawienie słów), nie poprawia się $\mathrm{w}$ tekście, przede wszystkim nie dodaje się żadnych słów w nawiasach czworograniastych ani też dopisków pod postacią „sic” lub inną lecz zaznacza się to jedynie w Odmianach tekstu (wariantach).

Nietkniętymi przez korekturę wydawcy pozostają wszelkie w rzeczywistości, czy na oko tylko n i eczyste rymy poety, również nie ustala się ich czystości, choćby raz zachodziły w postaci czystej, drugi raz w nieczystej.

Usterek rzeczowych, błędów w imionach własnych, w liczbach i datach, nie poprawia się w tekście - również nie poprawia się ani nie uzupełnia na podstawie oryginałów przytoczeń z dzieł obcych, kiedy są błędne, niedokładne i niezupełne - wszystko to, $\mathrm{z}$ uzasadnieniem należytym uskutecznia się jedynie w Odmianach tekstu ${ }^{12}$.

Bruchnalski sporządził wykaz problemów i wydobywał całą ich złożoność, ale ani on, ani Chorowiczowa, ani Stanisław Pigon ${ }^{13}$, konfrontujący pośmiertne publikacje wierszy Mickiewicza $z$ autografami, nie sprowokowali dyskusji, która mogłaby wykrystalizować odmienne stanowiska. Już po ukazaniu się pierwszych tomów Wydania Sejmowego Mickiewicza oraz po ogłoszeniu wstępu Juliusza Kleinera do Dzieł wszystkich Juliusza Słowackiego, Pigoń, rozgoryczony brakiem poważnej debaty, pisał:

I znowu rzecz znamienna: rozprawy te, znane od dziesięciu lat, nie wywołały echa; nikt głośno ani nie zaprotestował (chyba tylko tacendo), ani nie zakwestionował wytyczonych tam zasad, proponowanych rozwiązań trudności. Nie dlatego, żeby były bezsporne, nawet nie dlatego, żeby argumentom ich przyznano siłę dowodową nieodpartą, nie! Tylko po staremu przez „porządną niedbałość naszą”. Dopiero gdy jakiś jeden, nie zawsze jeden z najważniejszych, konkretny wypadek podnieci dyskusję, wtedy gotowo się okazać, że głębokie między nami różnice zapatrywań dotyczą niekiedy spraw wprost elementarnych. Jakoż rzeczywiście nie wszystko w tej dziedzinie jest ustalone i uregulowane raz na zawsze; miejsca na wątpliwości, na dyskusje, pod dostatkiem ${ }^{14}$.

W ciagu kolejnych 90 lat dyskusja się nie rozwinęła, powstawały natomiast

Ibidem, s. 126. Zob. też J. B ry a n t, Płynny tekst. Teoria zmienności tekstów i edytorstwa w dobie ksiażki i ekranu. Przeł. Ł. Cy bu ls ki. Warszawa 2020.

12 Bruchnalski, op. cit., s. 133.

13 S. Pi g on (Jakiego Mickiewicza znamy? Garść uwag o tekstach i autografach jego dziet. „Przegląd Warszawski” 1922, nr 12 〈wrzesień〉, s. 316) pisał bez ogródek: „trzeba podkreślić grubą linią, że wszystkie, bez wyjątku wszystkie odchylenia od tekstu autentycznego dokonały się na rachunek poprawności, z krzywdzącym poetę uchybieniem już to sensowi, już też pięknu, plastyce obrazu poetyckiego, rytmowi, wreszcie nawet rymowi”.

14 S. Pigoń, Kilka uwag o wydaniach krytycznych nowszych tekstów literackich. „Pamiętnik Literacki” t. 32 (1935), z. 1/4, s. 190-191. 
podręczniki coraz sztywniej definiujące zasady pracy edytora. Zamiast rozwijać dyskusję, stopniowo wypierano wątpliwości i zastrzeżenia pojawiające się w rozważaniach teoretycznych od samego początku. Książki Zbigniewa Golińskiego, który na przełomie lat sześćdziesiątych i siedemdziesiątych ubiegłego wieku próbował pokazywać, jak zmieniający się stosunek do tekstu wpływa na zmianę koncepcji edycji, również nie wywołały należytej reakcji.

Kiedy się czyta wstępy do współcześnie tworzonych wydań lub uczestniczy w konferencjach poświęconych tej problematyce, trudno uwolnić się od wrażenia, że tradycjonaliści desperacko bronią własnej, zanikającej tożsamości. Przygotowanie „właściwego, to jest poprawnego, zgodnego $\mathrm{z}$ intencją autorska, najlepszego kształtu dzieła”, zakłada oczyszczenie opracowywanych dokumentów z błędów i obcych ingerencji. Już w tym miejscu natykamy się na podstawową sprzeczność. Pojęcie błędu - Z wyjątkiem oczywistych literówek - jak od początku podkreślali to świadomi tekstolodzy, jest subiektywne, bo podporządkowane indywidualnemu odczuciu i językowej kompetencji osoby oceniającej tekst pod tym kątem. Edytor zbyt pochopnie utożsamia się $z$ autorem i przypisuje sobie wiedzę o jego prawdziwych, zniekształconych w procesie druku intencjach. Uzależnia więc te intencje od własnej wiedzy i wrażliwości. Modelowym przykładem, umieszczonym w podręcznikach jako wzór znakomicie wprowadzonej koniektury ${ }^{15}$, jest 940 wers czwartej księgi Pana Tadeusza, w którym Mickiewiczowskie „psy i charty” zamieniono na „pył i charty”, naruszając fonetyczne zestrojenie słów - proszę wymówić zbitkę głosek „pył i” ${ }^{\prime \prime}$. Dużo więcej komplikacji łączy się $\mathrm{z}$ kategorią obcych ingerencji. Dzieło literackie zwykle powstaje we współpracy różnych podmiotów - od czytających przyjaciół, przez redaktorów wydawniczych, po komentarze recenzentów i nacisk opinii społecznej. Wszystkie te podmioty mogą sugerować autorowi zmiany, które później za jego zgodą sa wprowadzane do tekstu ${ }^{17}$. Wiele $\mathrm{z}$ nich akceptuje, uznając, że poprawka tworzy lepszą wersję, inne akceptuje, nie zamierzając prowokować opinii publicznej. Czasem coś usuwa lub dodaje, uwzględniając zmieniającą się sytuację społeczną ${ }^{18}$ albo biorąc pod uwagę wrażliwość czytelników. Edytor nie ma prawa odwracać tego procesu i zakładać, iż autor sprzeniewierzył się własnej intencji, skoro podpisał się pod swoim tekstem i w ten sposób go zatwierdził.

Często jednak wśród literaturoznawców pojawia się myśl o powrocie do rękopiśmiennych wersji dzieła motywowana przekonaniem, że ulegając sugestiom współpracowników lub decydentów, autor odchodził od intencji pierwotnych, czyli najlepszych, należy więc do nich wrócić. Nigdy nie będziemy wiedzieli, dlaczego Mickiewicz $\mathrm{w}$ druku zrezygnował $\mathrm{z}$ istniejącego jeszcze $\mathrm{w}$ autografie fragmentu didaskaliów z pierwszej sceny Dziadów drezdeńskich: „Kilku więźniów młodych w szlafrokach ze świecami” ${ }^{19}$. Pozostawił: „Kilku więźniów młodych ze świecami”.

Zob. np. Loth, op. cit., s. 76.

Więcej na ten temat pisałam w artykule Niestabilny tekst „Pana Tadeusza” („Przekładaniec” 2020, nr 41 [w druku]).

J. Stilling er, Multiple Autorship and the Myth of Solitary Genius. Oxford 1991.

Pisałam o tym w artykule Niedoceniony katastrofizm Wacława Berenta (w: M. Pruss ak, Od słowa do słowa. Na marginesach krytyki tekstu. Warszawa 2013) na przykładzie jego Oziminy.

Zob. Z. Stef a now ska, Dodatek krytyczny. W: A. Mickiewi c z, Dzieła. T. 3: Dramaty. Oprac. Z. Stef a n owska. Warszawa 1995, s. 500. 
Nigdy nie rozstrzygniemy problemu, dlaczego drukując Dziady drezdeńskie, podniósł tonację utworu i usunął większość trywialnych momentów. Kusi myśl, że podporządkował się oczekiwaniom czytelników, ale nie da się jej udowodnić. Żaden nadmiernie gorliwy edytor nie zdobył się na to, by zakwestionować jego decyzję i przywrócić wersje rękopiśmienne ${ }^{20}$. Pytanie o intencje autora jest tu całkowicie bezzasadne - w różnych momentach procesu twórczego miał różne intencje ${ }^{21}$. Zbyt radykalni w rekonstrukcyjnym zapale wydawcy Mirona Białoszewskiego na podstawie rękopisu wprowadzili zmiany do autoryzowanych tekstów, kompilując „nowe odcenzurowane, poprawione i uzupełnione - edycje" 22 i naruszając delikatną strukturę starannie dopracowanych utworów. Te zabiegi sprawiły jednak, że czytelnik nie ma szansy poznać w całości żadnego $z$ dokumentów wykorzystanych przy konstruowaniu najnowszej, już nieautorskiej wersji Pamiętnika z powstania warszawskiego.

Problematyczna jest, oczywista na pozór, sytuacja ingerencji cenzury instytucjonalnej - dzieło dotarło do odbiorców w kształcie narzuconym przez opresyjny urząd, często pod wpływem tych ingerencji zostało przekształcone i uzupełnione przez autora, i jako takie zaczęło funkcjonować w obiegu czytelniczym w konkretnym historycznym momencie. Tym problemom poświęcona jest seria „Badania Filologiczne nad Cenzurą PRL”, redagowana przez Kamilę Budrowską. Inaczej niż autorzy prac zamieszczanych w tej serii sądzę, że przywracanie tekstu sprzed ingerencji cenzury nie może być rekonstruowaniem czegoś, co miałoby zastąpić dzieło, jakie w swoim czasie było czytane, recenzowane i wywierało wpływ na inne teksty kultury. Może być najwyżej traktowane jako jego zablokowana niegdyś wersja, udostępniona po latach. Publikowanie dzieł, w których do funkcjonującej latami książki wkleja się (często odmienną czcionka) fragmenty usunięte przez cenzurę, narusza integralność autoryzowanych wersji. Nie należy wypierać tekstu ogłoszonego przez autora $z$ procesu historycznoliterackiego.

Pojęciem $z$ krainy utopii jest także „edycja społecznie użyteczna”23, jak rozumiem taka, która przywraca historii literatury zapoznane dzieła albo udostępnia ich najbardziej, zdaniem edytora, poprawne wersje, ale również taka, która dostosowuje dawne teksty do zmieniających się czytelniczych możliwości odbiorców kolejnych epok. Nie da się obronić argumentu powołującego się na konieczność uwzględnienia perspektywy odbiorcy, którego edytor zamierza zwolnić z wysiłku trudnego obcowania $z$ dawnym tekstem. Problemem zasadniczym stają się więc zabiegi modernizacyjne i normalizacyjne, poprawiające autorską grafię, ortografię i gramatykę. Dzieje się to coraz częściej wedle $z$ góry przyjętych zasad, nawet „odmiany tekstu” nie rejestrują tych poprawek wprowadzonych do zapisu twórcy. W ten sposób czytelni-

Jeśli kogoś interesuje kształt rękopisu, zawsze może zajrzeć do podobizny autografu - A. Mi cki ewicz, Dziadów część III. Oprac. edytorskie Z. Stefa nowska, współpr. M. Prussak. [T. 1:] Podobizny autografów; [t. 2:] Transliteracje, komentarze. Warszawa 1998.

Zob. np. H. W. G able r, The Text as Process and the Problem of Intentionality. „Text” 1987, nr 3.

M. Białoszewski, Pamiętnik z powstania warszawskiego. Przygot. ed. tomu A. P op rawa. Warszawa 2014. Na okładce zamieszczono informację: „Nowa - odcenzurowana, poprawiona i uzupełniona - edycja Pamiętnika z powstania warszawskiego oparta jest na trzech źródłach, stanowi ich wypadkową. Celem było uzyskanie wersji możliwie najbliższej autorskich intencji”. 
cy z kolejnych epok mogą zyskać przekonanie, że język jest bytem od zawsze skodyfikowanym, historycznie niezmiennym. Nigdy się nie dowiedzą, że dawni autorzy pisali inaczej, nigdy nie będą ciekawi i zadziwieni osobliwością i różnorodnością form, których nie znają z codziennego użytku. Nie mówiąc już o daleko idących konsekwencjach modernizacji - niszczy ona autorskie aliteracje, wprowadza niespójność, zachowując stare formy w pozycjach rymowych i modernizując je wewnątrz wersu, likwiduje niuanse znaczeniowe, modernizując końcówki deklinacyjne ${ }^{24}$ i narzucając łączna pisownię „nie” $z$ imiesłowami, narusza tradycję i logikę systemu wersyfikacyjnego, podporządkowując składnię ortografii i likwidując wielkie litery na początku wersu, tak jak się to dzieje w serii „Biblioteka Pisarzy Staropolskich”. We współczesnych edycjach znika całkowicie dawna interpunkcja zastępowana przez normy kodyfikowane co kilkanaście lat. Dopóki nie została opracowana historia interpunkcji, brakuje uzasadnienia dla podejmowanych decyzji.

Zdarza się jednak, że nawet najbardziej świadomi edytorzy nie sa pewni własnych rozstrzygnięć. Czesław Zgorzelski opracowywał wiersze Mickiewicza trzykrotnie - w edycji krytycznej Dziet wszystkich (trzecia część pierwszego tomu, z której pochodzi cytowany dalej przykład ukazała się w roku 1981), w „Bibliotece Narodowej” (Wybór poezji, t. 2, 1986) i w Wydaniu Rocznicowym (t. 1, 1993). Wiersz o incipicie: „Te rozkwitłe świeżo drzewa”, w Dziełach wszystkich ma w tytule incipit ujęty w nawiasy kwadratowe, w Wyborze poezji sa dwa tytuły ujęte w nawiasy kwadratowe - incipit i dopisany na autografie obcą ręką [Pieśń pielgrzyma], Wydanie Rocznicowe powtarza incipit bez nawiasu kwadratowego oraz [Pieśń pielgrzyma]. $\mathrm{Z}$ wydania na wydanie zmienia się interpunkcja. Dzieła wszystkie odtwarzają interpunkcję autografu, przytoczę tylko jedną - czwartą zwrotkę:

\section{Zakochani to minstrele, \\ Pod oknem kochanki nuca, \\ Mnie nie bawią, ale smuca, \\ $\mathrm{Z}$ kim się muzyką podzielę? ${ }^{25}$}

W Wyborze poezji edytor zmienia przecinek w klauzuli trzeciego wersu na średnik, w Wydaniu Rocznicowym zachowuje ten średnik, ale, respektując współczesne normy, usuwa przecinek $\mathrm{z}$ pierwszego wersu.

Właściwy, poprawny, zgodny $z$ intencją autorska, najlepszy kształt dzieła jest więc utopią, lecz równocześnie ma uzasadniać arbitralność decyzji edytora, który gospodaruje w cudzym tekście zgodnie z własnymi upodobaniami. Przywołany tu liryk zachował się tylko w autografie w wersji brulionowej. Część tekstu jest zapisana w głównej kolumnie, na prawym marginesie, poniżej czwartej strofy znalazł

Groteskowy jest przykład wersu 1010 z czwartej części Dziadów. S t e fa n o w s k a (op. cit., s. 461) w tym miejscu zrezygnowała z modernizacji i tak to uzasadniła: „"Z tem liściem na czole“; zachowano dawną pisownię zaimka "tem" dla uwydatnienia - przy dzisiejszych zasadach pisowni niemożliwego - że chodzi o dawny rzeczownik zbiorowy "to liście»; Pet 29 [wyd. petersburskie] drukuje "s tém liściem", inne wydania "z tém liściem", ale Par 44 [wyd.: Paryż 1844] "z tym liściem", co znaczy, że jego wydawca nie zrozumiał już archaizmu i wyobraził sobie Gustawa z jednym liściem na głowie i - niestety - drugim w ręku (w. 1018), obraz zaiste śmieszny".

25 A. Mickiewicz, [„Te rozkwitłe świeżo drzewa...”]. W: Dzieła wszystkie. T. 1, cz. 3: Wiersze. 1829-1855. Oprac. Cz. Zgorze1ski. Wrocław 1981, s. 50. 
się czterowiersz, który edytorzy zgodnie włączają w ciąg wiersza jako zwrotkę piątą, oraz na wysokości strofy przedostatniej osiem linijek zapisanych niewatpliwie jednym ciagiem $z$ charakterystycznym dla Mickiewicza zjeżdżaniem kolumny tekstu do prawego marginesu. Niczego tu poeta nie skreślił, niczego nie wybrał, nie oddzielił zwrotek. Kolejni edytorzy tego wiersza uznawali, że mają do czynienia z wariantami jednego motywu, trzeba więc wybrać jeden czterowiersz spośród trzech. Tylko Eustachy Januszewski i Julian Klaczko w pierwodruku zachowali dwa czterowiersze - ten $z$ głównej kolumny, zapewne ze względu na paralelizm kończącego strofe pytania ${ }^{26}$, i pierwszy fragment marginesowego dopisku. W paryskich Pismach Mickiewicza są to zwrotki siódma i ósma:

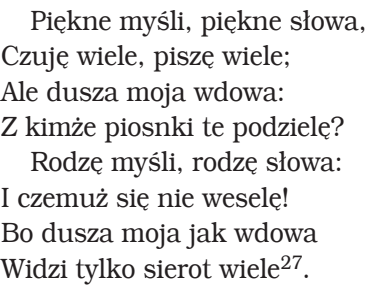

Wydawcy uzupełnili znaki interpunkcyjne (zwłaszcza wykrzyknik i dwukropki) i niedokładnie odczytali pierwszy wiersz, który w autografie (prawda, że niewyraźnym), ma postać: „Piękne nuty, piękne słowa”. Ten błąd skorygował Pigoń, ale równocześnie zakwestionował kształt wiersza.

Pigoń uważał, iż kilkakrotne opracowanie tego samego motywu oznacza, że mamy do czynienia $z$ wariantami i należy wybrać spośród nich ostatni, czyli najlepszy. Opuścił więc obie zwrotki uwzględnione w pierwodruku i do tekstu głównego włączył ostatnie cztery wiersze zapisane na marginesie:

\footnotetext{
Dzieci moje, myśli, słowa!

Czemuż $\mathrm{z}$ was się nie weselę?

Ach, bo dusza moja wdowa,

Dzieci wiele, - sierót wiele 28
}

i w ten sposób zlikwidował powracajacy paralelizm pytania, ale też sugerowany przez pytanie brak słuchaczy. Wprowadził wiele swoich znaków interpunkcyjnych, usuną natomiast istniejący w rękopisie na końcu czwartego wersu wykrzyknik. Uzasadniał tę decyzję dwojako, psychologią twórczości i estetyką:

Otóż właśnie ta redakcja trzecia, najpóźniejsza, dotychczas w ogóle nie drukowana, jest ostatnią wolą poety i ona tylko jedna powinna wejść w tekst główny, obie zaś drukowane dotychczas przenieść należy do wariantów. Ekonomia i zwięzłość wyrazu artystycznego zyska na tym w utworze najwyraźniej ${ }^{29}$.

Określenie „najpóźniejsza” jest niewątpliwie nadinterpretacją, skoro wszystkie

Druga zwrotka w tym wydaniu kończy się zdaniem zamkniętym wykrzyknikiem: „Z kimże wiosnę tę podzielę!” (A. M i c ki e w i c z, „Te rozkwitłe świeżo drzewa...” W: Pisma. T. 1. Paryż-Leipzig 1861, s. 414), Zgorzelski wstawił tu pytajnik, w autografie jest kropka.

27 Ibidem, s. 415.

28 A. Micki ew i c z, Pieśń pielgrzyma. W: Poezje. T. 1: Poezje rozmaite. (1817-1854). Wyd. przygot.

S. Pig oń. Lwów 1929, s. 410.

29 Pi goń, Jakiego Mickiewicza znamy?, s. 319. 
osiem wersów zapisano w tym samym momencie, jednym ciągiem. Poprawkę Pigonia powtarzają następne wydania. Nikt nie postawił sobie pytania, czy nie warto zachować dla czytelnika wahań autora krążącego wokół motywu wdowieństwa duszy jako kolejnego w jego twórczości obrazu samotności poety, którego niewysłuchane słowa od razu stają się sierotami. Ale w takiej sytuacji trzeba by pogodzić się $z$ tym, że edytor nie powinien podejmować decyzji za autora i że nie każdy brulion musi zyskać status dzieła wykończonego. Należałoby uznać, iż jakaś część literackiej spuścizny, zwłaszcza część, której autor nie ogłosił drukiem, może pozostać jako sprawdzanie różnych pomysłów, zapis poszukiwań nie doprowadzonych do końca, albo nawet warto zacząć od pytania, czy autor nie poszukuje innego, niż przywykliśmy sądzić, rozumienia spójności tekstu. Próbując podporządkować liryk Mickiewicza swoim estetycznym przekonaniom, edytorzy stają w gronie nie słyszących słuchaczy, bardon poety znów zabrzmiał głuchym tonem.

Imperatyw rozstrzygania wątpliwości sprawia, że edytor nie może pozostawić tekstu w formie niepełnej, nie może przyznać się do niewiedzy. Musi wprowadzać koniektury i uzupełnienia tam, gdzie czegoś brakuje. W innym Mickiewiczowskim liryku zachowanym tylko w brulionowym zapisie, zaczynającym się od incipitu: „Snuć miłość”, plama atramentu zakryła początek trzeciego wersu. Da się odczytać jedynie przedrostek „Ros...”30. Wydawcy uzupełniali urwane słowo rozmaicie. Zgorzelski dokładnie opisał te próby i możliwe mechanizmy snucia domysłów, warto w całości powtórzyć jego wywód:

Spod plamy atramentu w w. 3 nie daje się wywabić taki kształt pierwszego słowa, który by nie budził wątpliwości. Pigoń odczytywał je różnie: wpierw, w szkicu Jakiego Mickiewicza znamy?, proponował „Rozwijać”; po upływie kilku lat zawahał się, powracając do lekcji wprowadzonej w pierwodruku z r. 1880 i stale odtąd przed r. 1922 publikowanej: „Rozkładać”. Ale w edycji lwowskiej z 1929 r. (t. 1, s. 466) powrócił do własnej pierwotnej wersji:

Rozwijać ją, jak złotą blachę, gdy się kuje.

Tak też publikują ten wiersz oba ostatnie wydania, WN [Wyd. Narodowe] i WJ [Wyd. Jubileuszowe]. Wejrzenie $\mathrm{w}$ autograf budzi jednak pewne wątpliwości. Odczytać w nim można niemal bez wahań początek słowa: „ros” (co w pisowni Mickiewicza przed bezdźwięczną mogłoby także oznaczać „Roz”), i jego koniec: „ać”; zapis między nimi, trudny do odczytania z powodu plamy, składa się w przybliżeniu z 3-4 liter; zmieściłoby się w nim raczej „kład” niż „wij”. Ale równie dobrze mogłoby to być: „Rossnuwać”. Słowo to zdawałoby się nawet bardziej prawdopodobne, jako nawiązanie do czasownika w pierwszym wersecie utworu. Wszystkie trzy lekcje sa - oczywiście - równouprawnione, zanim jednak nowoczesne sposoby wydobywania wcześniejszych zapisów spod przekreśleń lub plam atramentu nie rozstrzygną tej wątpliwości, środkową część wyrazu należałoby ujmować w klamry dla oznaczenia, iż odczytujemy ją z domysłu, np. „Roz[snuw]ać” - notując jednocześnie w odmianach możliwość obu pozostałych lekcji ${ }^{31}$.

W żadnym wydaniu nie ma w tym miejscu nawiasów kwadratowych, czytelnicy nie wiedzą, rzecz jasna, że uzupełnienie pochodzi od edytora. Sam Zgorzelski we wszystkich swoich edycjach zrezygnował $z$ „Rozsnuwać” i wybrał lekcję „Rozkładać”. Grę w słowa można by pewnie prowadzić dalej, np. „Rozciagać”, toteż wyraz „oczywiście” musi budzić niepokój. Trudno uznać, iż niepewna koniektura

30 A. M i c ki e w i c z, 22. [Snuć miłość...]. W: Wiersze Adama Mickiewicza w podobiznach autografów. Cz. 2: 1830-1855. Oprac. Cz. Zgorzelski. Red. nauk. Z. Stefanowska, M. Kalin ows ka. Wrocław 1998, s. [93] (podobizna), s. 122 (transliteracja). 
zawsze jest oczywistością. Wiemy już także, że „nowoczesne sposoby” nie pomogły Zofia Stefanowska $\mathrm{z}$ pomocy w próbie odczytania tego, co jest pod kleksem, korzystała zarówno w pracowni konserwatorskiej Luwru, jak i w laboratorium policji. Bezskutecznie. Ponieważ edytorom zwykle nie udaje się uzgodnić konkretnych decyzji, to, jaką wersję czytamy, zależy od tego, po które wydanie sięgniemy. Jerzy Radziwiłowicz na pogrzebie profesor Marii Janion wrócił do wersji Pigonia i Borowego i wyrecytował: „Rozwijać ją, jak złotą blachę, gdy się kuje”. Najlepsza, naukowo opracowana edycja również i w tym przypadku okazuje się utopią. Bez szczegółowej wiedzy tekstologicznej nie da się uzgodnić, o którym utworze rozmawiamy. I znów wraca pytanie, czy nie lepiej przyznać się do bezradności, pozostawić tekst uszkodzony i nie dopisywać Mickiewiczowi słowa na podstawie li tylko domysłu, którego nie sposób uzasadnić.

Służebność działań wydawców dzieł nieżyjących twórców ma charakter paradoksalny. Edytor jest w istocie nie tyle gospodarzem, co władca decydujacym o kształcie cudzego tekstu. Na terytorium literaturoznawstwa pełni funkcję dominującą. Decyduje nie tylko o tym, które $z$ dawnych tekstów będą powszechnie dostępne, ale przede wszystkim o tym, jakie ich wersje stają się obiektem dalszych studiów. Często są to dzieła w kształcie, który za życia autora nigdy nie zaistniał, ale badacze przekonują, że właśnie one najlepiej oddaja jego intencje ${ }^{32}$. Edytor przystępuje do ich opracowania wyposażony w zespół własnych, nabytych w procesie edukacji, nawyków językowych, upodobań estetycznych i wyobrażeń na temat kształtu i funkcji dzieła literackiego, toteż rekonstruowanie intencji autora nazbyt często jest odzwierciedleniem indywidualnych gustów badacza. Eksperymenty formalne, śmiałe pomysły literackie - zwłaszcza jeśli chodzi o dzieła publikowane na podstawie rękopisów nie opracowanych przez autora - znikają wtłaczane w obowiązujące schematy i utrwalone konwencje estetyczne lub gramatyczne. Przykład Fantazego jest tu szczególnie dotkliwy. Trudno nie pytać, co utraciliśmy, czytajac dzieła edytorsko uporządkowane. Wystarczy wziąć do ręki dokumentacyjne wydanie Samuela Zborowskiego, żeby się przekonać o tym, co pozostawił Słowacki i w jaki sposób jego autografy różnią się od późniejszych edycji ${ }^{33}$.

W praktyce przygotowywania kolejnych edycji w Polsce niewiele się zmienia, choć od ponad 50 lat na świecie trwa żywiołowy spór o metody i zadania edytorstwa naukowego, zainspirowany różnorodnymi koncepcjami terminu „tekst” wypracowanymi w kręgu teorii literackich i teorii komunikacji. Omawia je szczegółowo David Greetham, założyciel Society for Textual Scholarship, w monumentalnej książce Theories of the Text ${ }^{34}$. Polemiści spotykają się, konfrontują swoje poglądy, wyostrza-

Zob. J. J. M c G a n n, A Critique of Modern Textual Criticism. Charlottesville, Va. - London 1992. P. B e m, „Zachować intencję autora”. O szlachetnym kłamstwie w edytorstwie naukowym. „Tekstualia” 2017, nr 1 .

33 Zob. M. Tros zyń s ki, Alchemia rękopisu. „Samuel Zborowski” Juliusza Słowackiego. Warszawa 2017. Zob. też A. M i c ki ew i c z, [Dans l'homme de Dieu...] / [W mężu Bożym...]. W: Prose artistique. Contes, essais, fragments / Proza artystyczna. Opowiadania, szkice, fragmenty. Wstęp, oprac. J. Pi etrzak-Théba ult. Warszawa 2013. - M. Prussak, Co mówia autografy „Romantyczności”? „Polska Sztuka Ludowa. Konteksty” 2017, nr 3. - W. Kr u s z e w s k i, Mickiewiczowski rękopis „No 38” raz jeszcze. „Sztuka Edycji” 2018, nr 1. Materialności tekstu został poświęcony oddzielny numer „Wielogłosu” (2017, nr 1). 
ją argumenty ${ }^{35}$. Dyskusje edytorów prowadzone są na łamach czasopism specjalistycznych (np. „Studies in Bibliography” wydawane od 1948 roku przez Bibliographical Society of the University of Virginia lub „Text” publikowany w latach 1994-2006 przez Indiana University Press, w roku 2006 przekształcony w „Textual Cultures") i tworza już pokaźną bibliotekę. Zasadnicze nurty tych sporów w kręgu angloamerykańskim omówił Łukasz Cybulski ${ }^{36}$, główne kierunki zostały przedstawione w kompendium The Cambridge Companion to Textual Scholarship ${ }^{37}$, obie książki zawierają obszerną bibliografię. Tekst jest dzisiaj rozumiany jako etap różnorodnych procesów dokonujących się pomiędzy autorem - wydawnictwem (medium) - odbiorca, a nie jako dzieło wyabstrahowane z procesu twórczego za pomoca specjalistycznych metod edytorskich. Zmieniający się stosunek do tego pojęcia zwalnia edytorów z konieczności publikowania wersji najlepszych, najbliższych intencji autora, ponieważ wielokrotnie już udowodniono, że takie wersje nie istnieja.

Problemem badacza i czytelnika jest konieczność dokonania wyboru między studiowaniem procesu powstawania i dynamiki różnych wersji dzieła połączonego jednym tytułem a jednym $z$ etapów funkcjonowania tego dzieła w obiegu czytelniczym, między akceptacja jego wielowariantowości a wyborem jednego momentu $z$ historii jego oddziaływania w świecie literatury ${ }^{38}$. Często wśród dokumentów tekstowych znajdują się wersje robocze, nie przeznaczone dla odbiorców. Porównywanie ich $z$ tekstami opublikowanymi nie przynosi informacji o przebiegu pracy autora - taka wiedza wynika $z$ dokładnego prześledzenia przekształceń. Uznanie odrębności kolejnych wariantów każe zrezygnować z zestawiania tradycyjnie rozumianych odmian tekstu. Na każdym etapie procesu twórczego powstają inne wersje - inne nawet wtedy, jeśli różnią je tylko drobne poprawki. Zestawianie ich synchroniczne, na poziomie pojedynczych wyrazów, fraz a nawet całych zdań rozbija ich spójność i falsyfikuje dynamikę ewolucji tekstu. To banalna prawda, że o sensie frazy decyduje macierzysty kontekst, a nie zestawienie $z$ paralelną frazą wyjętą $\mathrm{z}$ innego kontekstu. Odmienne wersje powstające w różnym czasie pełnią w procesie powstawania dzieła różne funkcje. Od początku XIX wieku inna jest rola przekazów rękopiśmiennych, inna tekstów drukowanych. Jedne dokumentują proces twórczy, drugie efekty tego procesu. Czasem rękopisy zamykaja jakiś etap tego procesu i bywaja przeznaczone dla jednego adresata - tak było np. w przypadku rękopiśmiennych zbiorków wierszy Zbigniewa Herberta. Zarazem jednak po oddaniu dzieła do druku proces twórczy się nie kończy, autor, doprowadzając przyszłych edytorów do konfuzji, nanosi poprawki na wydrukowany egzemplarz (jak Mickiewicz na Panu Tadeuszu) albo publikuje nowe, zmienione wersje tekstu (jak Wyspiański przerabiający swoje dramaty, czasem bardzo radykalnie, wystarczy przypomnieć

Zob. np. artykuły zebrane w książce Devils and Angels. Textual Editing and Literary Theory (Ed. Ph. Co he n. Charlottesville, Va. - London 1991).

Ł. Cybulski, Krytyka tekstu na rozdrożach. Anglo-amerykańska teoria edytorstwa naukowego $w$ drugiej połowie XX wieku. Warszawa 2017.

The Cambridge Companion to Textual Scholarship. Ed. N. Fr a i s t a t, J. Fl a n d e r s. Cambridge, Mass., 2013.

Zob. La Naissance du texte. Ensemble réuni par L. Hay. Paris 1989. - P.-M. de Biasi, Genetyka tekstów. Przeł. F. Kwi a tek, M. Pru s s a k. Warszawa 2015. 
dwie redakcje Warszawianki, z których tylko jedną wybiera się jako tekst główny, i dwie redakcje Legendy traktowane przez edytorów jako odrębne dramaty).

Jeśli się nie uwzględni odmienności etapów procesu twórczego, powstają edycje tak mylace, jak „transliteracja autografu” Vade-mecum Cyprian Norwida opracowana na dodatek na podstawie skanów dostępnych na stronie Biblioteki Narodowej, opublikowana $z$ adnotacja „Literaturoznawstwo. Edycje krytyczne”39. Edytor nie może poprzestać na transliteracji skanów, jeśli oryginały są dostępne, to elementarna zasada tej pracy. Wielowarstwowy autograf Norwida jest zapisem odwróconego procesu twórczego. Na czystopisie gotowym do wydrukowania i ostatecznie nie przyjętym przez wydawnictwo poeta nanosił kolejne zmiany redakcyjne, posługując się różną wielkością liter, rozmaitymi kolorami ołówka, doklejając kartki i wycinając inne. Wszytko to działo się stopniowo, niejednocześnie. Linearna, drukowana jedną czcionką transliteracja, przenosząca w dodatku dużą część informacji do opisu w komentarzach pod tekstem, nie pozwala zrekonstruować dynamiki procesu twórczego, a z perspektywy nowych technik opracowywania wielowarstwowych rękopisów jest całkowicie anachroniczna. Modelowym przykładem wykorzystania technologii cyfrowej w pracy $\mathrm{z}$ rękopisem moga być autografy Samuela Becketta i ich opracowanie w Samuel Beckett. Digital Manuscript Project ${ }^{40}$. Wizualizacje procesu twórczego na podstawie rękopisów Aleksandra Puszkina przedstawiał Georgij Wiekszyn na konferencji Przed-tekstowy świat. Archiwa, bruliony, rękopisy, zorganizowanej w marcu 2016 w Krakowie przez Instytut Badań Literackich PAN i Uniwersytet Jagielloński. Wykorzystanie nowych technik, które pomagaja wyodrębnić kolejne nawarstwienia w autografach, omówił Paweł Bem w artykule Ton manuskryptu. Literatura - edycja - życie $e^{41}$. Przytoczył wiele przykładów stron internetowych zamieszczających efekty pracy $\mathrm{z}$ autografami.

Nowe perspektywy tekstologiczne zmuszają do wypracowania całkowicie nowej koncepcji edycji, uwzględniającej także nie przewidywane wcześniej możliwości technologii cyfrowych ${ }^{42}$. Lepiej nie ulegać złudzeniu, że jest to najlepszy sposób na przekroczenie ograniczonych możliwości aparatu krytycznego, który w cyfrowym świecie mógłby być bardziej dynamiczny i pomieścić więcej przykładów odmiennych wersji $^{43}$. Problem nie polega bowiem na prostym przeniesieniu myślenia o tekście ze środowiska druku do środowiska cyfrowego. Trzeba zmienić podejście do zagadnienia i, sformułowawszy zakres oczekiwanych zadań, jakie powinna spełnić nowoczesna edycja, do nich dobrać najlepsze oprogramowanie, co wymaga współdziałania specjalistów $z$ wielu dziedzin, obdarzonych jednak podobną wyobraźnią. Jak dotąd, technika cyfrowa dobrze sprawdza się przy tworzeniu archiwów - służy bądź publikowaniu dokumentów składających się na dossier konkretnego dzieła

C. N orw id, Vade-mecum. Transliteracja autografu. Oprac., wstęp M. G ra b ow s ki. Łódź 2018. Samuel Beckett. Digital Manuscript Project. Na stronie: https://www.beckettarchive.org/ (data dostępu: 12 IX 2020).

41 Ukaże się w tegorocznym numerze 20 pisma „Forum Poetyki / Forum of Poetics”.

42 Zob. np. Electronic Text: Investigations in Method and Theory. Ed. K. Sutherland. Oxford 1997. - Text Editing, Print and the Digital World. Ed. M. D e e g a n, K. Su the rl a nd. London New York 2016.

43 O ich ograniczeniach pisał P. Shilling s burg w ksiażce From Gutenberg to Google. Electronic Representations of Literary Texts (Cambridge, Mass., 2006). 
(np. wśród wielu innych - osobna strona poświęcona Pani Bovary ${ }^{44}$ ), bądź twórczości jednego autora (tu lista stron jest bardzo duża, dostępna w licznych publikacjach). Przygotowanie koncepcji zarówno cyfrowego archiwum, jak i cyfrowej edycji pojedynczego dzieła (nie należy jej utożsamiać ze zarchiwizowanym dossier tegoż dzieła, które powinno poprzedzać edycję) zawsze jest pracą autorską, także wówczas, gdy tworzy ją zespół. Taka koncepcja może powstać po zbadaniu i zinterpretowaniu rozpoznanych dokumentów. Dobór, sposób uporządkowania i zaprezentowania dostępnych źródeł zależy od tego, co zostanie przez autorów koncepcji uznane za ważne, a co za mniej istotne. Nie chodzi o mechaniczne zeskanowanie dokumentów, tylko o ich udostępnienie i skomentowanie. Obiektywizm pracy edytora okazuje się kolejnym złudzeniem, z którego trzeba zrezygnować.

Badania edytorów w ostatnich latach rozchodzą się w trzech kierunkach. Dowartościowane zostały studia nad historią tekstu, nad dziejami jego publikacji i recepcji. Donald McKenzie, który ten obszar badań określał jako „historical bibliography”, sądził nawet, iż będzie on centralnym problemem studiów nad tekstem ${ }^{45}$. O tyle miał rację, że bez szczegółowych badań w tej dziedzinie nie da się stworzyć sensownego projektu archiwum cyfrowego. Inspirowane krytyka genetyczną studia tekstologiczne, $z$ jednej strony pokazuja jak wiele istotnych problemów umyka naukowcom, jeśli poprzestają na interpretowaniu wersji tekstu przygotowanej przez najbardziej sumiennych nawet edytorów, $z$ drugiej natomiast dowodzą, jak wiele jeszcze wiedzy na temat konkretnego utworu i wyobraźni autora można wyczytać, śledząc kolejne wersje dzieła i mechanizm wprowadzanych zmian. Kiedy czytam odrzucone przez autora fragmenty publikowanych dzieł Mickiewicza, nie mogę odżałować tych, do których docieraja jedynie czytelnicy komentarzy edytorskich. Na oddzielną rozprawę zasługuje kończąca Widzenie Księdza Piotra replika Aniołów, skreślona w czystopisie:

Usnał! - Uwolnim duszę z ciała jak z powicia
Białego senne dziecię, i zmysłów sukienkę
Lekko zwleczmy, rozwiążmy wszystkie wstążki życia,
Nad świat lećmy ją skąpać w promieniach jutrzenki,
I nieśmy senną, czystą, nieśmy w niebo trzecie,
Ojcu wielkiemu złożyć na kolanach dziecię:
Niech swą pobłogosławi sennego pieszczotą.
A przed ranną modlitwą duszę wrócim życiu
I ukryjemy w ciała czystego powiciu,
I położym w samotność jak w kolebkę złotą ${ }^{46}$.

W wersji opublikowanej poeta uwzniośla swojego bohatera, inaczej widzi zależność duszy, ciała i zmysłów, odbiera tej scenie tkliwość, a Księdzu Piotrowi samotność. W druku „złotą kolebką” jest ciało - z niego, z tej kolebki, Aniołowie wyjmą dusze ,jak dziecinę" i nad ranem tam ją z powrotem włożą, do ciała-kolebki. Tak

Na stronie: https://www.bovary.fr/ (data dostępu: 12 IX 2020).

D. F. M c Kenzi e, Bibliography and the Sociology of Text. Cambridge, Mass., 1999. Zob. też recenzję pierwszego wydania książki J. M c G a n n, Theory of Texts („London Review of Books” t. 10 〈1988〉, nr 4. Na stronie: https://www.lrb.co.uk/the-paper/v10/n04/jerome-mcgann/theory-of-texts 〈data dostępu: 12 IX 2020〉).

Cyt. za: Stefanowska, Dodatek krytyczny, s. 510. Pominęłam tu słowa skreślone wewnątrz tego fragmentu. 
ważny dla Mickiewicza motyw samotności zyskuje w tym fragmencie jeszcze jeden wymiar. Dynamika procesu twórczego okazuje się nowym, odkrywającym pasjonujące aspekty tekstu, obszarem badań ${ }^{4}$, jak się można przekonać, studiując konkretne przykłady, niezbędnym przy opracowywaniu koncepcji edycji.

Tymczasem każda kolejna publikacja omawiająca możliwości i ograniczenia działań edytora poszerza skalę wątpliwości i zastrzeżeń oraz prowadzi do wniosku, że jednej spójnej koncepcji edytorskiej nie da się zaproponować, każda edycja, jeśli zrezygnuje z poszukiwania stabilnej „intencji autora”, pomija jakiś aspekt dziejów i form opracowywanego dzieła ${ }^{48}$. Nie oznacza to wszakże, że trzeba porzucić myśl o przygotowaniu edycji opracowanej krytycznie. Porzucając myśl o obiektywizmie „tekstu najlepszego”, można zaproponować przemyślaną, dostosowaną do charakteru opracowywanego tekstu, autorska propozycję, z podstawowym założeniem, iż edytor będzie miał szczegółową wiedzę na temat historii kształtowania i społecznego funkcjonowania dzieła. Wtedy z pełną świadomością wybierze jedną $z$ wersji, uzasadni motywy i konsekwencje swojego wywodu, a także nie będzie ingerował w tekst dokumentu. Ale też omówi historię kształtowania się tekstu i te jego aspekty, których ta konkretna edycja nie uwzględnia, i zainteresowanemu czytelnikowi uświadomi, że ma do czynienia z jednym etapem złożonego procesu powstawania tekstu literackiego, że dostaje do ręki edycję variorum. Tych wszystkich informacji nie uniesie tradycyjny aparat krytyczny, potrzebna będzie nowa formuła przekazania wiedzy o tekście. Współczesny edytor ma przed sobą bardzo długą listę dylematów, które musi rozważyć i jakoś je rozstrzygnąć, jeśli chce doprowadzić do końca publikację dzieła zgodną z elementarnymi standardami wiedzy.

Abstract

MARIA PRUSSAK Institute of Literary Research of the Polish Academy of Sciences, Warsaw ORCID 0000-0003-1432-8368

\section{TWILIGHT OF CRITICAL EDITIONS?}

The article discusses the problems and possibilities of the contemporary academic edition. Editorial preparations of texts by late authors throughout the $20^{\text {th }}$ century underwent more and more rigid normalisation. Discussions in Poland mainly referred to specific solutions, though they rather seldom raised the issues of text theory and criticism, broadly developed and examined both in Western and in Russian literary studies. In effect of the stiffening rules, the crucial pieces of information about the text failed to be included within an edition, and it almost completely neglected the text-forming issues. The knowledge about the transformations of a given work may extend its interpretive potential. Solution to the problems addressed within the framework of text criticism, against its initial assumptions, will not be worked out on the ground of text criticism unless concepts of digitisation designed to individual works separately are developed.

Zob. np. M. Ant on i k, Słowo raz obudzone. Poezja Czesława Miłosza: próby czytania. Kraków 2015. - Archiwa i bruliony pisarzy. Odkrywanie. Red. M. Prus sak, P. B e m, Ł. Cybulski. Warszawa 2017. - P. B e m, Dynamika wariantu. Miłosz tekstologicznie. Warszawa 2017. - Pracownia Herberta. Studia nad procesem tekstotwórczym. Red. M. Antoniuk. Kraków 2017. Przed-tekstowy świat. Z literackich archiwów XIX i XX wieku. Red. M. W o źn i a k- Ła b i e n i e c. Łódź 2020.

48 Zob. zwłaszcza P. Shillingsburg, Negotiating Conflicting Aims in Textual Scholarship. The Problem of Editorial Intentions. W: From Gutenberg to Google. 